\title{
Annual Inhalation Dose of Indoor Radon and Thoron in Mizoram, India
}

ISSN: 2576-8840

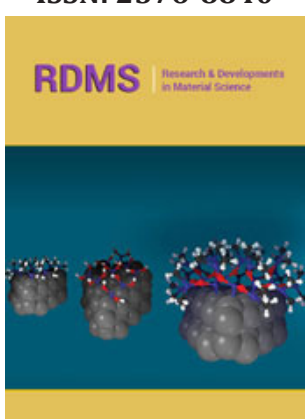

*Corresponding author: Chhangte LZ, Department of Physics, Govt Zirtiri Residential Science College, Aizawl, Mizoram, India

\section{Submission: 洫 February 03, 2021}

Published: 制 March 05, 2021

Volume 15 - Issue 1

How to cite this article: Chhangte LZ, Zoliana B, Sahoo BK, Sapra BK Pachuau Z, Zirlianngura. Annual Inhalation Dose of Indoor Radon and Thoron in Mizoram, India. Res Dev Material Sci. 15(1). RDMS.000852. 2021. DOI: 10.31031/RDMS.2021.15.000852

Copyright@ Chhangte LZ. This article is distributed under the terms of the Creative Commons Attribution 4.0 International License, which permits unrestricted use and redistribution provided that the original author and source are credited.

\author{
Chhangte $\mathrm{LZ}^{1 *}$, Zoliana $\mathrm{B}^{2}$, Sahoo $\mathrm{BK}^{3}$, Sapra $\mathrm{BK}^{3}$, Pachuau $\mathrm{Z}^{4}$ and Zirlianngura ${ }^{5}$ \\ ${ }^{1}$ Department of Physics, Govt. Zirtiri Residential Science College, Aizawl, Mizoram, India \\ ${ }^{2}$ Department of Electronics, Govt. Zirtiri Residential Science College, Aizawl, Mizoram, India \\ ${ }^{3}$ Radiological Physics and Advisory Division, Bhabha Atomic Research Centre, Mumbai, India \\ ${ }^{4}$ Department of Physics, Mizoram University, Aizawl, Mizoram, India \\ ${ }^{5}$ Department of Chemistry, Govt. Zirtiri Residential Science College, Aizawl, Mizoram, India
}

\begin{abstract}
Annual inhalation dose of indoor radon and thoron have been measured using Solid State Nuclear Track Detector (LR-115 type-II) based Twin Cup Dosimeter with single entry and Direct Progeny Sensors (DPS) in Mizoram, which has the highest lung cancer incidence rates among males and females in India. The measurement was carried out in 50 dwellings selected primarily from the background gamma radiation level measured using Micro-R survey meter and the construction type of the building. The annual inhalation dose of indoor radon and thoron are found to be $1870.68 \pm 10 \mu \mathrm{Sv} / \mathrm{y}$ and $631.7 \pm 4 \mu \mathrm{Sv} / \mathrm{y}$ respectively which are higher than the global average values but within the ICRP recommendation.
\end{abstract}

\section{Introduction}

About $87 \%$ of the radiation dose received by mankind is due to natural radiation sources and the remaining $13 \%$ by anthropogenic radiation [1]. The worldwide average natural radiation dose to humans is about $0.3-1.0 \mathrm{mSv} /$ year which is four times higher than the world average of artificial radiation exposure [2]. The most important component of natural radiation exposure to the public is due to the inhalation of indoor radon, thoron and their decay products which constitute about $54 \%$ of natural radiation [3]. As radon/thoron gases are inhaled, densely ionizing alpha particles emitted by the short-lived decay products of radon/thoron can interact with biological tissue in the lungs leading to DNA damage and results into lung cancer [4]. Since majority of the residents use to spend most of the time at indoors, the knowledge of the indoor concentration of radon, thoron and their progenies is of utmost importance.

To calculate the annual indoor inhalation dose of radon and thoron, their indoor concentration, progenies concentration and their equilibrium factors must be calculated first. In the present study, passive measurement technique has been followed for measurement of indoor radon and thoron concentration, using Solid State Nuclear Track Detector (LR-115 Type-II) in Pin-Hole Based Twin Cup Dosimeters with single entry developed by Bhabha Atomic Research Centre (BARC), Mumbai [5]. To measure the progenies concentration, deposition base Direct Radon/Thoron Progeny Sensor (DRPS/DTPS) were used [6-8]. Dwellings were selected according to the gamma level measured using Gamma Survey Meter and the building type. The GPS co-ordinates have also been recorded for each dwelling in which dosimeters and DRPS/DTPS were installed for proper location assessments.

\section{Study Area}

The geographical location of the study area is Saiha and Lawngtlai districts of Mizoram, India within Latitude- $22^{\circ} 29^{\prime} 28.3^{\prime \prime}$ to $22^{\circ} 36^{\prime} 59.4^{\prime \prime}$ and Longitude $92^{\circ} 59^{\prime} 14.3^{\prime \prime}$ to $92^{\circ} 52^{\prime} 22.0^{\prime \prime}$ with altitude ranging from $1866 \pm 10$ feet to $3807 \pm 10$ feet from the sea level.

\section{Methods}

\section{Indoor radon $\&$ thoron}

The LR-115 type-II plastic track detectors (SSNTDs) kept in the Dosimeter was deployed 
in 50 dwellings of 8 different villages of Lawngtlai and Saiha District, Mizoram India from $3^{\text {rd }}$ July 2015 to $22^{\text {nd }}$ June 2016. Due to maximum occupancy, bedrooms were chosen for deployment of the dosimeters. After more than 90 days of exposure in dwellings, the detectors were removed and subjected to chemical etching in $2.5 \mathrm{~N}$ $\mathrm{NaOH}$ solutions at $60{ }^{\circ} \mathrm{C}$ for 90 minutes in a constant temperature bath. Then these films were washed and dried. The track density was obtained by using the standard spark counter (Model PSI-SC1) with operating voltage $(500 \mathrm{~V})$ and the pre-sparking voltage $(900 \mathrm{~V})$ of the spark counter, which has been established before these measurements [9] (Figure 1).
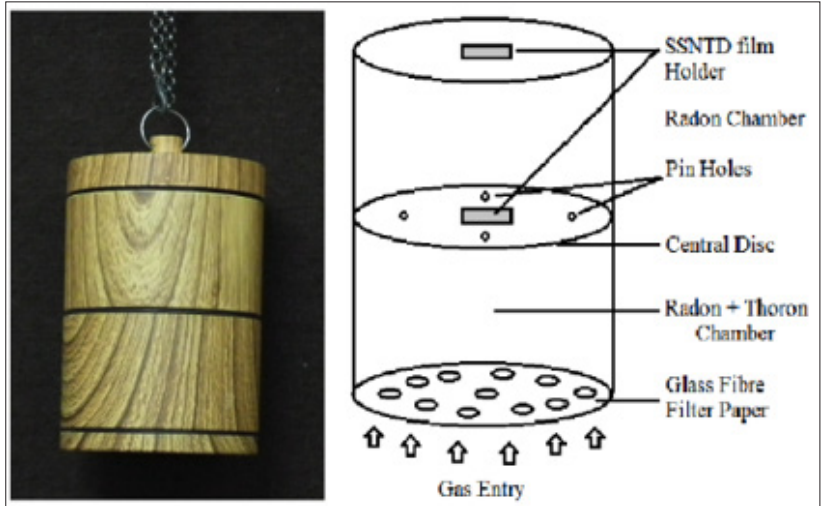

Figure 1: Pin-hole base dosimeter.
The track density recorded on the detector in the Radon Chamber and Radon+Thoron Chamber were converted into radon and thoron concentrations according to the following formulae

$$
C_{R}\left(\frac{B q}{m^{3}}\right)=\frac{T_{R}}{\text { Calibration factor } \times \text { Exposure period (days) }}
$$

where $C_{R}$ is the radon concentration and $T_{R}$ are the tract density of detector in Radon Chamber. Calibration factor used $=0.0172 \pm 0.002$ [5].

$$
C_{T}\left(\frac{B q}{m^{3}}\right)=\frac{T_{F}-T_{P}}{\text { Calibration factor } \times \text { Exposure period (days) }}
$$

where $C_{T}$ is the thoron concentration, $T_{F}$ is the track density of films in Radon chamber and $T_{P}$ is that for Radon+Thoron chamber. Calibration factor used $=0.010 \pm 0.001$ [5].

\section{Progeny measurement}

The concentrations of progenies are determined through Equivalent Equilibrium Radon/Thoron Concentrations (EERC \& EETC). The EEC of radon/thoron is equal to that quantity of radon/ thoron concentration which is in secular equilibrium with its progeny nuclides giving equivalent potential alpha energy concentration (PAEC) for the progeny nuclides actually present in the atmosphere. EERC and EETC were measured by deposition based Direct Progeny Sensors (DRPS/DTPS) in bare modes [8] (Figure 2).

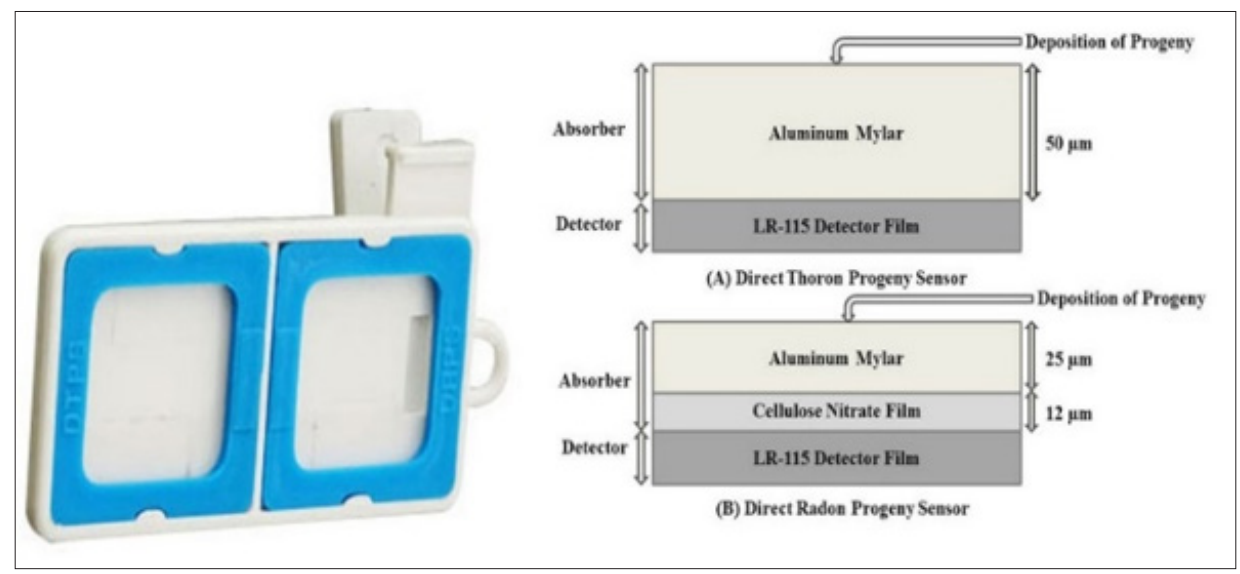

Figure 2: DRPS \& DTPS.

DTPS element is made up of LR-115 type II mounted with $50 \mu \mathrm{m}$ aluminized mylar to selectively detect only $8.78 \mathrm{MeV}$ alpha particle emitted from ${ }^{212} \mathrm{Po}$; while DRPS is made up of LR-115 type II mounted with aluminized mylar plus cellulose nitrate of effective thickness $37 \mu \mathrm{m}$ to detect mainly $7.69 \mathrm{MeV}$ alpha particle emitted from ${ }^{214} \mathrm{Po}$. The basic principle of operation of these sensors is that the detector detects the alpha particles emitted from the deposited progeny atoms. The tracks formed are recorded in the exposed LR-115 type II film is related to Equilibrium Equivalent Progeny Concentration (EEC) using the sensitivity factor [6]. The DRPS and DTPS are hanged along with the dosimeter on the ceiling of the bedroom for a minimum of 90 days. The detectors were then etched and subjected to Spark counting.
The track density obtained using DTPS can be used directly to calculate the EETC, since the comparatively larger thickness (50 $\mu \mathrm{m})$ of the absorber used in DTPS does not allow radon progeny to pass through it and hence there is no interference from radon progeny to thoron progeny. Formulae used to calculate EETC is as follows $[6,8]$

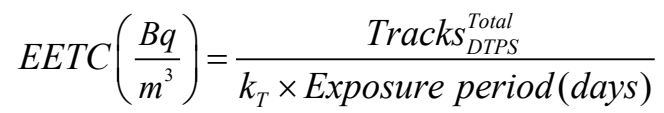

where $k_{T}$ is the calibration factors for DTPS. The values of calibration factors for DTPS in natural environment have been calculated by [10] to be equal to 0.94 Tracks $\mathrm{cm}^{-2} \mathrm{~d}^{-1} / \operatorname{EETC}\left(\mathrm{Bqm}^{-3}\right)$. In case of EERC, since the energy of ${ }^{212} \mathrm{Po}$ (thoron progeny) is higher than that of ${ }^{214} \mathrm{Po}$ (radon progeny), the alpha particles emitted from 
both radon progeny and thoron progeny pass through the absorber $(37 \mu \mathrm{m})$ used in the DRPS and hence to calculate EERC, the tracks produced by the thoron progeny are eliminated as calculated from DTPS, using the equation [8]

$$
\operatorname{Tracks}_{D R P S}^{\text {OnlyRP } \mathrm{Pro}}=\operatorname{Tracks}_{D R P S}^{\text {Total }}-\frac{\eta_{R T}}{\eta_{T T}} \times \text { Tracks }_{\text {DTPS }}^{\text {Total }}
$$

where, $\eta_{R T}(=0.01 \pm 0.0004$ / alpha particle $)$ and $\eta_{T T}(=0.08 \pm 0.004 /$ alpha particle $)$ are the track registration efficiencies of thoron progeny in DRPS and that in DTPS, respectively, Tracks ${ }_{D R P S}^{\text {onlpn Pro }}$ is the tracks density recorded on DRPS due to only radon progeny and Tracks DRPS $_{\text {Total }}$ and Tracks DTPS Tre the abbreviations for total track density recorded on DRPS and DTPS, respectively. Formulae used to calculate EERC $[6,8]$ is given as follows

$$
\operatorname{EERC}\left(\frac{B q}{m^{3}}\right)=\frac{\text { Tracks }_{D R P S}^{\text {OnlyR } \mathrm{Pr} o}}{k_{R} \times \text { Exposure period(days) }_{\text {pros }}}
$$

where $k_{R}$ is the calibration factors for DRPS. The values of calibration factors for DRPS in natural environment have been calculated by [10] to be equal to 0.09 Tracks $\mathrm{cm}^{-2} \mathrm{~d}^{-1} / \operatorname{EETC}\left(\mathrm{Bqm}^{-3}\right)$.

\section{Equilibrium factors}

The equilibrium factor or the sensitivity factor for the radon $\left(\mathrm{F}_{\mathrm{R}}\right)$ and thoron $\left(\mathrm{F}_{\mathrm{T}}\right)$ are the quantity of ultimate interest in passive dosimetry applications. In the literature on inhalation dosimetry, it is conventional to express $\mathrm{F}_{\mathrm{T}}$ as the track density expected for 1-day exposure to an environment containing $1 \mathrm{~Bq} / \mathrm{m}^{3}$ of EETC. Likewise, $\mathrm{F}_{\mathrm{R}}$ represents the track density expected for 1-day exposure to an environment containing $1 \mathrm{~Bq} / \mathrm{m}^{3}$ of EERC after subtracting the track density expected from $1 \mathrm{~Bq} / \mathrm{m}^{3}$ of EETC.

The following formulae are used to obtain the sensitivity factor (equilibrium factor) of radon and thoron respectively [8].

$$
\begin{gathered}
F_{R}=\frac{\operatorname{EERC}\left(B q / \mathrm{m}^{3}\right)}{C_{R}\left(B q / \mathrm{m}^{3}\right)} \\
F_{T}=\frac{\operatorname{EETC}\left(\mathrm{Bq} / \mathrm{m}^{3}\right)}{C_{T}\left(B q / \mathrm{m}^{3}\right)}
\end{gathered}
$$

where $C_{R}$ and $C_{T}$ are the concentration of radon and thoron

\section{Inhalation dose}

Annual inhalation dose rate is the amount of radon and/ or thoron inhaled per annum ( $\mu \mathrm{Sv} / \mathrm{yr}$ ) by individuals indoor. Inhalation dose can be calculated using the obtained concentrations of the parent nuclei and the progenies.

Several models have been developed to assess the inhalation dose rates to the population due to radon, thoron and their progeny [11]. Lung dose distribution assessment carried out by different agencies right from 1956 to 2000 given in details in UNSCEAR reports. [12] shows a large variation in dose conversion factors. The estimated dose conversion factors varied drastically based on the breathing rate as well as the target tissue. Based on these, the dose conversion factors were derived, which has been used for the compilation of the inhalation dose rate (D) as shown below

$$
\begin{gathered}
D_{R}(n S v / h)=\left(0.17+9 F_{R}\right) C_{R} \\
D_{T}(n S v / h)=\left(0.11+40 F_{T}\right) C_{T}
\end{gathered}
$$

where numerical numbers are the dose conversion factors for gas and progeny concentrations [12].

\section{Result and Discussion}

(Figure 3); (Table 1) Indoor radon, thoron and their progeny concentration have been calculated in 50 (only 31 can be compared) dwellings situated in 8 different villages/town of Saiha and Lawngtlai District of Mizoram. The observed annual average concentration of indoor radon in the dwellings has been varying from $52.73 \pm 5 \mathrm{~Bq} / \mathrm{m}^{3}$ to $143.36 \pm 8 \mathrm{~Bq} / \mathrm{m}^{3}$ with the average value of $89.50 \pm 7 \mathrm{~Bq} / \mathrm{m}^{3}$, and that of thoron varying from $17.39 \pm 13 \mathrm{~Bq} / \mathrm{m}^{3}$ to $53.57 \pm 21 \mathrm{~Bq} / \mathrm{m}^{3}$ with the average value of $34.60 \pm 17 \mathrm{~Bq} / \mathrm{m}^{3}$. The annual average indoor radon and thoron concentration obtained is on the higher side of the average worldwide indoor radon $(40 \mathrm{~Bq} /$ $\mathrm{m}^{3}$ ) and thoron $\left(10 \mathrm{~Bq} / \mathrm{m}^{3}\right)$ concentration [13] and national average values (42 and $12.2 \mathrm{~Bq} / \mathrm{m}^{3}$ ) [8]. However, the indoor radon or thoron level are well below the action level recommended by the WHO and ICRP $[14,15]$.

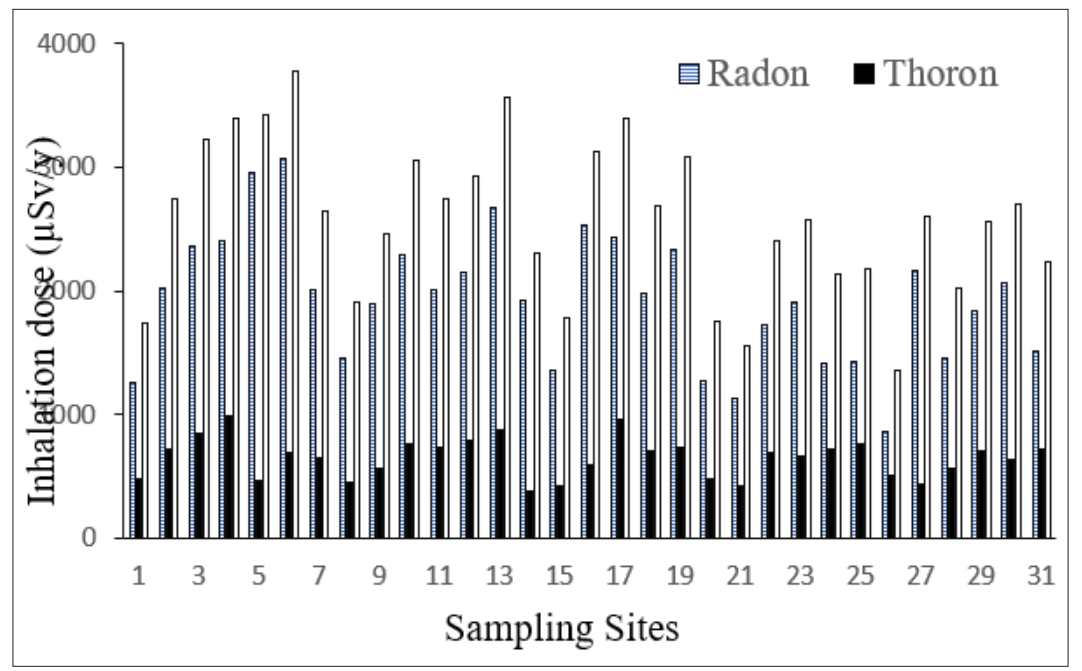

Figure 3: Annual average inhalation dose. 
Table 1: Annual average indoor radon, thoron and progenies concentration $(\mathrm{Bq} / \mathrm{m} 3)$, equilibrium factors and inhalation dose $(\mu \mathrm{Sv} / \mathrm{y})$.

\begin{tabular}{|c|c|c|c|c|c|c|c|c|}
\hline & $\begin{array}{c}\text { Radon } \\
\text { Conc. }\end{array}$ & $\begin{array}{c}\text { Thoron } \\
\text { Conc. }\end{array}$ & $\begin{array}{c}\text { Radon Pro. } \\
\text { Conc. }\end{array}$ & $\begin{array}{c}\text { Thoron Pro. } \\
\text { Conc }\end{array}$ & $\begin{array}{c}\text { Radon Equi } \\
\text { Factor }\end{array}$ & $\begin{array}{c}\text { Thoron Equi. } \\
\text { Factor }\end{array}$ & $\begin{array}{c}\text { Radon Inha. } \\
\text { Dose }\end{array}$ & $\begin{array}{c}\text { Thoron Inha. } \\
\text { Dose }\end{array}$ \\
\hline Min & 52.73 & 17.39 & 9.82 & 0.78 & 0.18 & 0.02 & 856.86 & 290.62 \\
\hline Max & 143.36 & 53.57 & 27.24 & 2.73 & 0.39 & 0.34 & 3075.24 & 988.09 \\
\hline Avg & 89.5 & 34.6 & 15.04 & 1.71 & 0.27 & 0.08 & 1870.68 & 631.7 \\
\hline GM & 87.06 & 32.83 & 14.06 & 1.64 & 0.26 & 0.06 & 1794.28 & 609.17 \\
\hline SD & 21.3 & 11.09 & 6.6 & 0.47 & 0.07 & 0.07 & 536.23 & 166.76 \\
\hline GSD & 1.266 & 1.391 & 1.594 & 1.235 & 1.276 & 1.919 & 1.342 & 1.318 \\
\hline
\end{tabular}

The calculated annual average value of EERC has been varying from $9.82 \pm 1 \mathrm{~Bq} / \mathrm{m}^{3}$ to $27.24 \pm 2 \mathrm{~Bq} / \mathrm{m}^{3}$ with the average value of $15.04 \pm 2 \mathrm{~Bq} / \mathrm{m}^{3}$, and that of EETC varies from $0.78 \pm 0.1 \mathrm{~Bq} / \mathrm{m}^{3}$ to $2.73 \pm 0.6 \mathrm{~Bq} / \mathrm{m}^{3}$ with the average value of $1.71 \pm 0.1 \mathrm{~Bq} / \mathrm{m}^{3}$. The average indoor progeny concentrations of radon and thoron lie under $17 \mathrm{~Bq} / \mathrm{m}^{3}$ and $3 \mathrm{~Bq} / \mathrm{m}^{3}$ respectively which are the safe limits recommended by [15] in the dwellings.

The annual average Equilibrium Factor for radon has been varying from $0.18 \pm 0.02$ to $0.39 \pm 0.03$ with the average value of $0.27 \pm 0.03$ which is lower than the globally assumed value of 0.4 [12] and that of thoron varies from $0.02 \pm 0.006$ to $0.34 \pm 0.003$ with the average value of $0.08 \pm 0.01$ which is smaller than the globally assumed value of 0.1 [16].

The annual average indoor radon inhalation dose has been varying from $856.86 \pm 7 \mu \mathrm{Sv} / \mathrm{y}$ to $3070.24 \pm 12 \mu \mathrm{Sv} / \mathrm{y}$ with the average value of $1870.68 \pm 10 \mu \mathrm{Sv} / \mathrm{y}$ and that of thoron varies from $290.62 \pm 3 \mu \mathrm{Sv} / \mathrm{y}$ to $1140.41 \pm 5 \mu \mathrm{Sv} / \mathrm{y}$ with the average value of $631.7 \pm 4 \mu \mathrm{Sv} / \mathrm{y}$. This result is higher than the global average values $(1100 \mu \mathrm{Sv} / \mathrm{y}$ for radon $\& 90 \mu \mathrm{Sv} / \mathrm{y}$ for thoron). The Total Inhalation Dose varies from $1362.25 \pm 10 \mu \mathrm{Sv} / \mathrm{y}$ to $3774.68 \pm 18 \mu \mathrm{Sv} / \mathrm{y}$ with the average value of $2502.38 \pm 14 \mu \mathrm{Sv} / \mathrm{y}$ and GM of $2419.67 \mu \mathrm{Sv} / \mathrm{y}$ (GSD 1.302). This result is within the national average value (0.27-5.14mSv/y) reported by [17] and lower than the upper value for annual dose level $(10 \mathrm{mSv} / \mathrm{y})$ recommended by [18].

\section{Conclusion}

i. Annual Average Indoor Radon, thoron and their progeny concentrations in the study area are found to be under the safe limits recommended by [15] but higher than the national average.

ii. The annual average equilibrium factor for radon and thoron are found to be lower than the globally assumed values.

iii. The annual inhalation dose of radon and thoron are higher than the global average, but the total average indoor inhalation lies within the national average and [18] recommended value. Contribution of inhalation dose rate due to thoron and its progeny is seen to be about $25 \%$ of the total inhalation dose rate.

\section{Acknowledgement}

The Authors are grateful to Radiological Physics and Advisory Division, Bhabha Atomic Research Center for providing necessary equipment and all the resident in the study area who have helped in carrying out this study.

\section{References}

1. Kannan V, Rajan MP, Iyengar MR, Ramesh R (2002) Distribution of natural and anthropogenic radionuclides in soil and beach sand samples of Kalpakkam (India) using hyper pure germanium (HPGe) gamma ray spectrometry. Appl Radiat Isot 57(1): 109-119.

2. UNSCEAR (2008) Vol I Annexure B. Exposure to the public and workers from various sources of radiation. Report to the General Assembly. New York, United Nations, p. 234.

3. UNSCEAR (1994) United nations scientific committee on the effects of atomic radiation, ionizing radiation: Sources and biological effects. New York, USA.

4. Edling C, Wingreen G, Axelson O (1986) Quantification of the lung cancer risk from radon daughter exposure in dwellings- An epidemiological approach. Environment International 12(1-4): 55-60.

5. Sahoo BK, Sapra BK, Kanse SD, Gaware JJ, Mayya YS (2013) A new pinhole discriminated ${ }^{222} \mathrm{Rn} /{ }^{220} \mathrm{Rn}$ passive measurement device with single entry face. Radiation Measurements 58: 52-60.

6. Mishra R, Mayya YS (2008) Study of a deposition-based Direct Thoron Progeny Sensor (DTPS) technique for estimating equilibrium equivalent thoron concentration (EETC) in indoor environment. Radiation Measurements 43(8): 1408-1416.

7. Mishra Rosaline, Sapra BK, Mayya YS (2015) Emerging trends in ${ }^{222} \mathrm{Rn}$ and ${ }^{220} \mathrm{Rn}$ decay products detection. Solid State Phenomena 238: 134139.

8. Mishra Rosaline, Mayya YS, Kushwaha HS (2009) Measurement of ${ }^{220} \mathrm{Rn} /{ }^{222} \mathrm{Rn}$ progeny deposition velocities on surfaces and their comparison with theoretical models. Journal of Aerosol Science 40(1): $1-15$.

9. Azimi Garakani D, Shahbazi M, Latifi G (1981) A new automatic spark counting system. Nuclear Tracks 4(3): 141-149.

10. Mishra R, Prajith R, Sapra BK, Mayya YS (2010) Response of direct thoron progeny sensors (DTPS) to various aerosol concentrations and ventilation rates. Nuclear Instruments and Methods in Physics Research Section B: Beam Interactions with Materials and Atoms 268(6): 671675.

11. Ramu SC, Shaikh AN, Muraleedharan TS, Ramachandran TV (1992) Measurements of indoor radon levels in india using solid-state nuclear track detectors: Need for standardization. Defen Sc Jour 42(4): 219-225. 
12. UNSCEAR (2000) Annexure B. Exposures from natural radiation, Report to the general assembly with scientific annexes, United Nations. Pp: 84141.

13. Nazaroff WW, Nero AV (1988) Radon and its decay products in indoor air. John Wiley \& Sons, New York, USA.

14. WHO (2009) WHO handbook on indoor radon: A public health perspective. Geneva, Switzerland, p. 94.

15. ICRP (1993) Protection against ${ }^{222} \mathrm{Rn}$ at home and at work. Annals of ICRP 23(2): 1-39.
16. UNSCEAR (1993) United nations scientific committee on the effects of atomic radiation. Sources, effects and risks of ionizing radiation. Report to the General Assembly, New York, United Nations.

17. Ramachandran TV, Mayya YS, Sadashivan S, Nair RN, Eappen KP (2003) Radon-thoron levels and inhalation dose distribution patterns in indian dwellings. BARC Report Mumbai, Government of India, pp: 1-63.

18. ICRP (2007) The 2007 recommendations of the international commission on radiological protection. Annals of ICRP, ICRP Publication, pp: $1-34$.

For possible submissions Click below:

Submit Article 